\title{
Distribution of Endophyllum sempervivi (Pucciniales) in Ukraine
}

\author{
Yuri Ya. TYKHONENKO, Vasyl P. HELUTA \\ M.G. Kholodny Institute of Botany, National Academy of Sciences of Ukraine \\ 2, Tereshchenkivska Str., Kyiv 01004, Ukraine \\ yu.ya.tykhonenko@gmail.com
}

Tykhonenko Yu.Ya., Heluta V.P. Distribution of Endophyllum sempervivi (Pucciniales) in Ukraine. Ukr. Bot. J., 2017, 74(1): $71-75$.

M.G. Kholodny Institute of Botany, National Academy of Sciences of Ukraine

2, Tereshchenkivska Str., Kyiv 01004, Ukraine

Abstract. Epiphytotic development of the rust fungus Endophyllum sempervivi was recorded in May 2016 in the cemetery of Borzova village (Volhynian Region, Ukraine) on Jovibarba globifera, a host species and genus new for Ukraine. In northern Europe (Belgium, Denmark, Ireland, Netherlands, Norway, Sweden, UK), USA (northeastern states) and Canada (Ontario) E. sempervivi occurs beyond the area of natural distribution of Sempervivum and Jovibarba; however, it is apparently absent in Morocco, Spain south of the Pyrenees, Italy south of the Alps and in west Asia (the Caucasus) despite the presence of indigenous species of Sempervivum. A list of all localities in which E. sempervivi was recorded in Ukraine is provided. The article is illustrated by micrographs obtained by scanning electron microscopy.

Keywords: Jovibarba, Sempervivum, rust fungi, distribution, morphology

\section{Introduction}

The genus Endophyllum Lév. comprises rusts producing only spermogonia and telia similar to spermogonia and aecia of Puccinia Pers. or Uromyces (Link) Unger. Their teliospores can be distinguished from normal aeciospores only on germination. Endophyllum sempervivi (Alb. \& Schwein.) de Bary parasitizes Sempervivum L. and Jovibarba Opiz species of the Crassulaceae. Both host genera are closely related and have their origins in the European mountains, but in the Quaternary the distribution of Sempervivum expanded into northern Africa (the High Atlas Mountains of Morocco) and southwest Asia (the mountains of Turkey, the Caucasus and northern Iran) (Klein, Kadereit, 2015). Sempervivum ruthenicum Schnittsp. \& C.B. Lehm., occurring in Romania, Moldova, Ukraine and southwestern Russia, is one of a few lowland species of the genus. Most records of E. sempervivi are on Sempervivum, while finds on Jovibarba are scarce (Denchev, 1995; Henderson, 2000; Mułenko et al.,

(C) Yu.Ya. TYKHONENKO, V.P. HELUTA, 2017
2008). Hitherto, this species was recorded in Ukraine only on $S$. ruthenicum.

The aim of this publication is to report a record of $E$. sempervivi on the new for Ukraine host genus and collate all currently known data on the localities of this fungus in Ukraine.

\section{Materials and methods}

A specimen collected in the field was labelled and dried for further treatment. Aecial teliospores mounted in water and/or lactic acid were investigated by light microscopy under Primo Star microscope and AxioVision 4.7 software, used as well for measurements of microstructures. For scanning electron microscopy samples were coated with an ultrathin coating of gold by ion beam sputtering unit JFC-1100. Images were obtained by scanning electron microscope JEOL JSM6060 LA.

The specimen is deposited in Mycological Reference Collection of M.G. Kholodny Institute of Botany, National Academy of Sciences of Ukraine $(K W-M)$. 


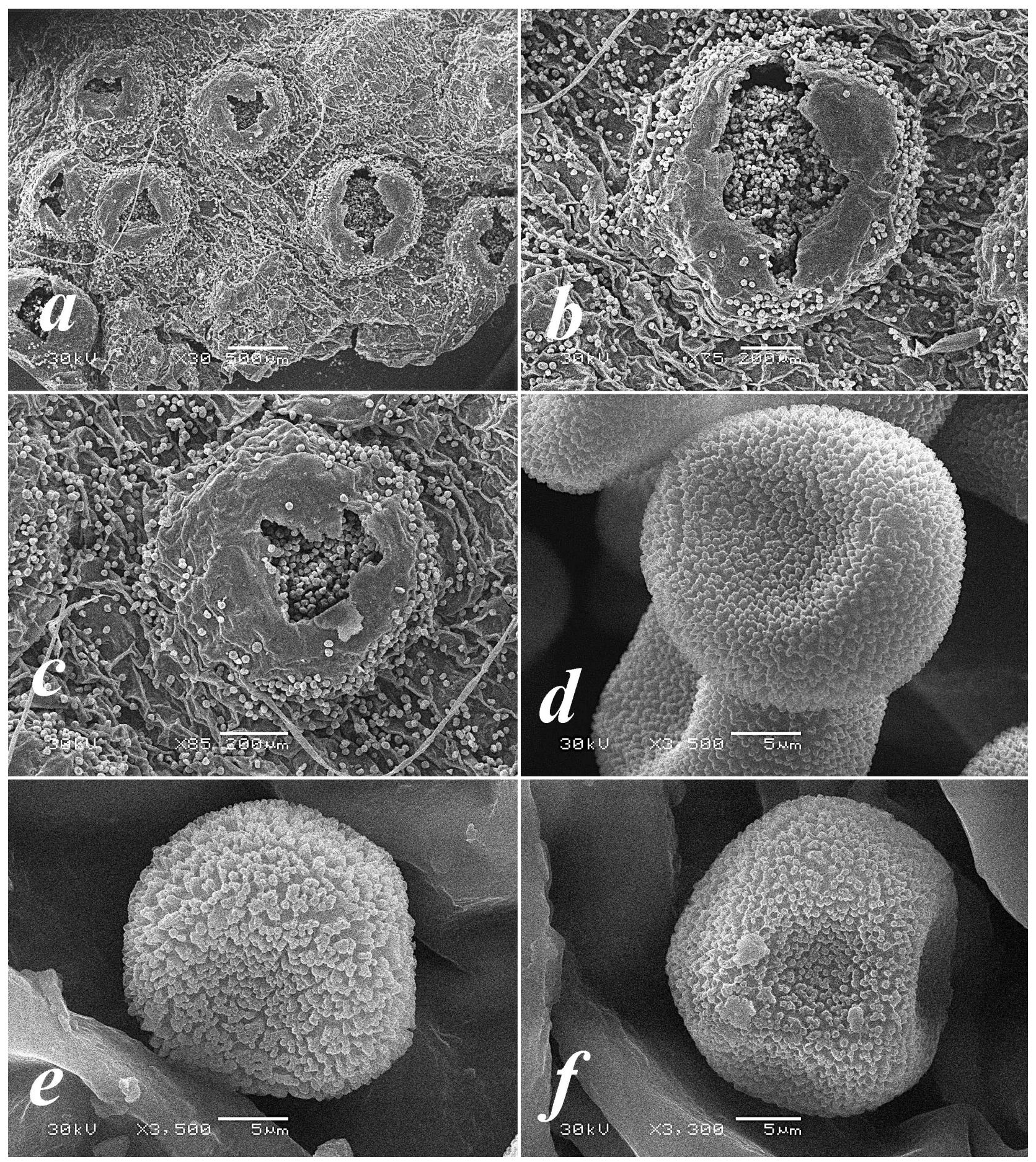

Fig. 1. Endophyllum sempervivi on Jovibarba globifera: $a, b, c-$ telia; $d, e, f$ - teliospores. Scale bars: $a-500 \mu \mathrm{m} ; b, c-200 \mu \mathrm{m}$; $d, e, f-5 \mu \mathrm{m}$ 


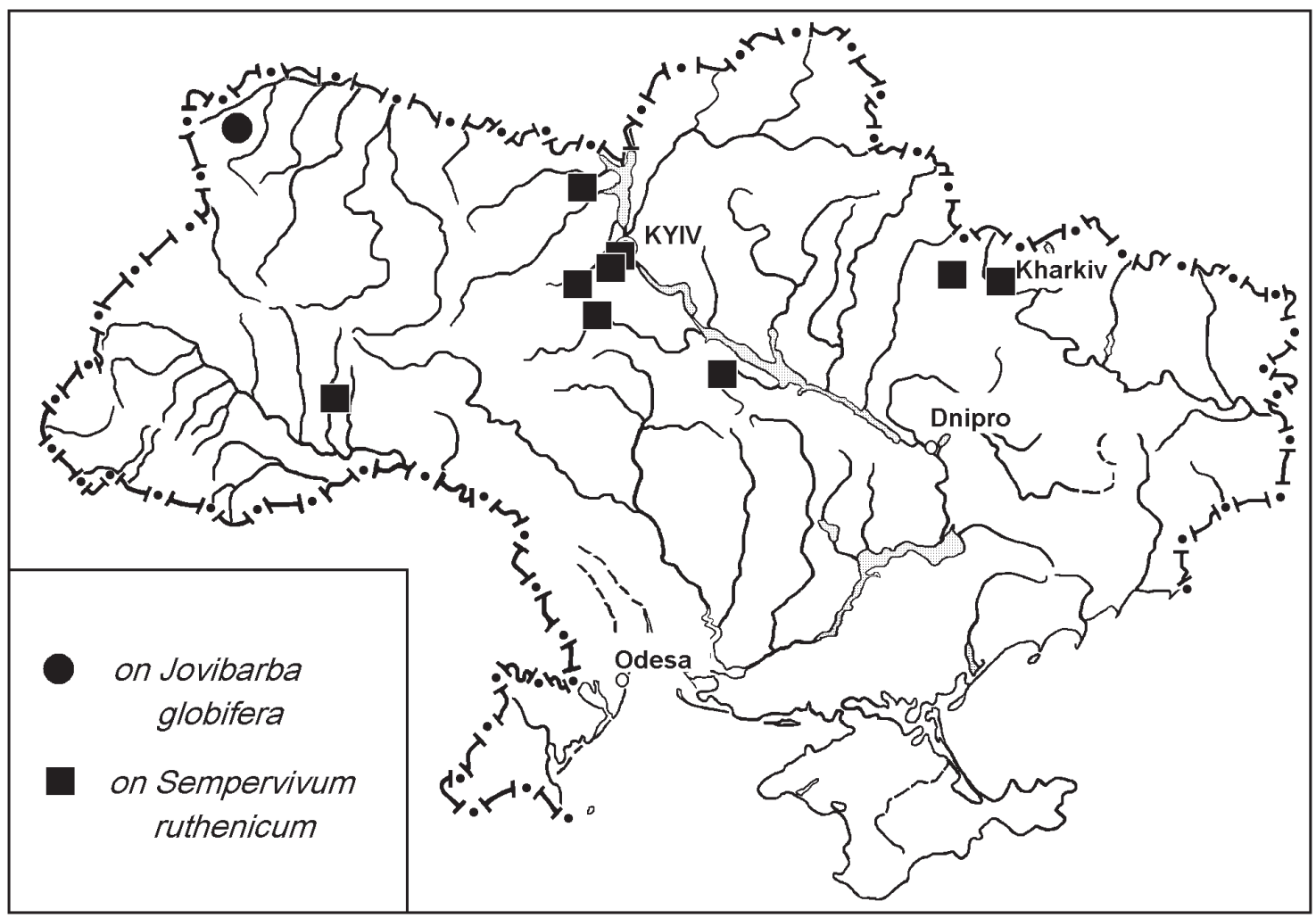

Fig. 2. Distribution of Endophyllum sempervivi in Ukraine

\section{Results and discussion}

At the cemetery of Borzova village (Volhynian Region, Ukraine) an epiphytotic development of the rust fungus Endophyllum sempervivi was recorded on a new for Ukraine host, Jovibarba globifera (L.) J. Parn. The synonymic names, description of spermogonial and telial stages, host plants and data on distribution in Ukraine of this species are provided below. Original illustrations are followed by information on its morphology and ecology.

Endophyllum sempervivi (Alb. \& Schwein.) de Bary, Annls Sci. Nat., Bot., sér. 4, 20: 86. 1863. - Uredo sempervivi Alb. \& Schwein., Consp. fung. (Leipzig): 126. 1805. - Caeoma sempervivi (Alb. \& Schwein.) Link, in Willdenow, Sp. pl., ed. 4 6(2): 27. 1825.

Spermogonia scattered amongst telia on both sides of leaves (mostly on upper side), globoid, brownish, $100-140 \mu \mathrm{m}$ in diameter. Telia on both sides of leaves of systemically infected plants, sunken in the leaf tissue, usually cover a big part of the leaf blade. Peridium aecidioid, $0.8-1.5 \mathrm{~mm}$ in diameter, yellowish, opening at the top by irregular pore (Fig. 1, $a, b, c$ ). Peridium cells in cross-section irregularly roundish, with external walls $2.5-4 \mu \mathrm{m}$ thick, almost smooth, internal 2.5$3 \mu \mathrm{m}$ thick, densely covered with hemispherical warts. Peridium cells are loosely connected; between them and the epidermis is a thick layer of hyphae. Teliospores nearly spherical or broadly oval, slightly angular, 22$30 \times 18-28 \mu \mathrm{m}$. Wall yellowish-brown, $2.5-4 \mu \mathrm{m}$ thick, densely and distinctly verrucose (Fig. $1, d, e, f)$.

\section{Distribution in Ukraine (Fig. 2)}

On Jovibarba globifera: Volhynian Region, Stara Vyzhivka District, Borzova, cemetery, $51^{\circ} 25^{\prime} \mathrm{N}$, $24^{\circ} 27^{\prime} \mathrm{E}, 01.05 .2016$, V.P. Heluta ( $\left.K W-M 70593\right)$.

On Sempervivum ruthenicum: Cherkasy Region, Smila, $49^{\circ} 13^{\prime} \mathrm{N}, 31^{\circ} 51^{\prime} \mathrm{E}, 10.06 .1915$ (Kaznovskiy, 1915), ibid., 07.05.1923, G. Newodowski ( $K W-M$ 22476). Kharkiv, $50^{\circ} 00^{\prime} \mathrm{N}, 36^{\circ} 13^{\prime} \mathrm{E}, 05.1873$ (Potebnya, 1910). Kharkiv Region, Krasnokutsk District, Slobozhanskyi National Nature Park, $50^{\circ} 00^{\prime} \mathrm{N}, 35^{\circ} 16^{\prime} \mathrm{E}, 16.04 .2016$, observation by N. Saidakhmedova. Khmelnytskyi Region, Chemerivtsi, $49^{\circ} 00^{\prime} \mathrm{N}, 26^{\circ} 21^{\prime} \mathrm{E}, 02.05 .1927$, observation by F.S. Panasiuk. Kyiv, Koncha-Zaspa, $50^{\circ} 17^{\prime} \mathrm{N}, \quad 30^{\circ} 34^{\prime} \mathrm{E}, \quad 02.05 .1956$, observation by M.Ya. Zerova. Kyiv Region, Bila Tserkva, $49^{\circ} 47^{\prime} \mathrm{N}$, $30^{\circ} 06^{\prime}$ E, 30.05.1926, V.P. Hrodzinska ( $K W-M$ 22468); 
ibid., 29.05.1927 (Hrodzinska, 1929); Boyarka, $50^{\circ} 19^{\prime} \mathrm{N}, 30^{\circ} 17^{\prime} \mathrm{E}, 27.05 .1924$ (Tselle, 1925); Ivankiv District, Starosillia, $51^{\circ} 21^{\prime} \mathrm{N}, 30^{\circ} 12^{\prime} \mathrm{E}, 04.05 .1931$, M.G. Kholodny $(K W-M$ 22467, $K W-M$ 22473, $K W-M$ 22474, $K W-M$ 22475); ibid., 20.05.1931, M.G. Kholodny $(K W-M$ 22466, $K W-M$ 22470, $K W-M$ 22472); ibid., 20.05.1932, Z.K. Hizhytska $\left(K W-M\right.$ 22471); Fastiv District, Skryhalivka, $50^{\circ} 05^{\prime} \mathrm{N}$, $29^{\circ} 43^{\prime}$ E, 05.04.1973, Z.G. Lavitska ( $\left.K W-M 22465\right)$.

General distribution. Many cultivars of houseleeks are widely grown in cemeteries and gardens beyond the natural range of Sempervivum and Jovibarba. Therefore, E. sempervivi occurs not only within the native range of its hosts (Austria, Bulgaria, Czech Republic, France, Germany, Italy, Poland, Romania, southwestern Russia, Serbia, Slovakia, Spain, Switzerland, Ukraine) but also in the northern part of Europe (Belgium, Denmark, Ireland, Netherland, Norway, Sweden, UK). At the beginning of the $20^{\text {th }}$ century, it was introduced to North America (Reed, 1917) and at present is known from Canada (Ontario) and the USA (northeastern states). Endophyllum sempervivi is also recorded for Turkey (Henderson, 1964; Bahçecioğlu, Kabaktepe, 2012), but not on indigenous species of Sempervivum (on S. globiferum L. = J. globifera).

Endophyllum sempervivi is apparently absent in Morocco, Spain south of the Pyrenees, Italy south of the Alps and in west Asia (the Caucasus) despite the presence of indigenous species of Sempervivum.

In terms of phenology, E. sempervivi is a spring species producing spermogonia and telia from April onwards (majority of its records were made in May). Infection results in a perennating mycelium which spreads through tissues of the host plant and overwinters there. On renewal of activity in the spring, the mycelium passes to the leaves and causes hypertrophy by elongation (Ashwort, 1935). The infected leaf contains more auxine than an uninfected one (Pilet, 1952), and may reach two, three or four times the normal size for the species. It is assumed that E. sempervivi produces substances which inhibit degradation of auxins, and this is the cause of the appearance of parasitized plants (Pilet, 1952).

Most frequently E. sempervivi occurs in dry habitats. Our specimen was also collected in a rather arid site, the infected host plants were growing in dry sandy soil of a village cemetery.

\section{Acknowledgements}

We are grateful to V.I. Sapsay from the staff of the M.G. Kholodny Institute of Botany for his assistance in scanning electron microscopy of $\mathrm{E}$. sempervivi and to Ms N. Saidakhmedova for information on distribution of this fungus in one of localities in Kharkiv Region.

\section{REFERENCES}

Ashworth D. An experimental and cytological study of the life history of Endophyllum sempervivi. Trans. Br. Mycol. Soc., 1935, 19(3): 240-258.

Bahçecioğlu Z., Kabaktepe Ş. Checklist of rust fungi in Turkey. Mycotaxon, 2012, 119: 494.

Denchev C.M. Bulgarian Uredinales. Mycotaxon, 1995, 55: 405-465.

Henderson D.M. Uredinales from S. W. Asia: III. The rust fungi of Turkey. Notes Roy. Bot. Gdn. Edinb., 1964, 25: 197-277.

Henderson D.M. Checklist of the Rust Fungi of the British Isles, Kew: Brit. Mycol. Soc., 2000, 36 p.

Hrodzinska V.P. Zapysky Bilotserkivskoho silskohospodarskoho politekhnikumu, 1929, 1(1): 193-200. [Гродзінська В.П. Матеріяли до грибної флори Білоцерківщини (із робіт катедри сільськогосподарської ботаніки). Записки Білоцерків. с.-г. політехнікумy, 1929, 1(1): 193-200].

Kaznovskiy L. Tr. Byuro po prikl. botan., 1915, 8(8): 929960. [Казновский Л. Материалы по микофлоре окрестностей м. Смелы Киевской губ. 1913 года. Тр. бюро по прикл. ботанике, 1915, 8(8): 929-960].

Klein J.T., Kadereit J.W. Phylogeny, biogeography, and evolution of edaphic association in the European oreophytes Sempervivum and Jovibarba (Crassulaceae). Int. J. Plant Sci., 2015, 176(1): 44-71.

Mułenko W., Majewski T., Ruszkiewicz-Michalska M. A Preliminary Checklist of Micromycetes in Poland. Biodiversity of Poland, Krakow: W. Szafer Institute of Botany, Polish Acad. Sci., 2008, vol. 9, 752 pp.

Pilet P.E. Problème hormonal concernant l'Endophyllum sempervivi. Bull. Soc. Bot. Suisse, 1952, 62: 269-274.

Potebnya A.A. Trudy Obshchestva ispytateley prirody pri Imperatorskom Kharkovskom universitete, 1910, 43: $203-$ 241. [Потебня А.А. Материалы к микологической флоре Курской и Харьковской губерний. Тр. общ-ва испытат. природы при Императ. Харьк. ун-те, 1910, 43: 203-241].

Reed G.M. The discovery of Endophyllum sempervivi (Alb. \& Schw.) deBary in North America. Torreya, 1917, 17: 84-85.

Tselle M.O. Hrybni khvoroby roslyn na Kyivshchyni v 1923$24 r$ r., Kyiv: Kyiv. stantsiya zakhystu roslyn vid shkidnykiv (STAZRO), 1925, 28 pp. [Целле М.О. Грибні хвороби рослин на Київині в 1923-24 рр., Київ: Київ. станція захисту рослин від шкідників (СТАЗРО), 1925, c. 1-28].

Recommended for publication by V.P. Hayova
Submitted 07.11.2016

Ukr. Bot. J., 2017, 74(1) 
Тихоненко Ю.Я., Гелюта В.П. Поширення в Україні Endophyllum sempervivi (Pucciniales). Укр. бот. журн., 2017, 74(1): 71-75.

Інститут ботаніки ім. М.Г. Холодного НАН України вул. Терещенківська, 2, Київ 01004, Україна

У травні 2016 р. на кладовищі с. Борзова (Волинська обл., Україна) був відмічений епіфітотійний розвиток гриба Endophyllum sempervivi на Jovibarba globifera - новому для України виді й роді живильних рослин. У Північній Европі (Бельгія, Великобританія, Данія, Ірландія, Нідерланди, Норвегія, Швеція), Канаді (Онтаріо) і США (північно-східні штати) E. sempervivi трапляється поза ареалом природного поширення Sempervivum і Jovibarba але, очевидно, відсутній у Марокко, Іспанії на південь від Піренеїв, Італії на південь від Альп і в західній Азії (Кавказ), незважаючи на присутність там аборигенних видів роду Sempervivum. У статті наведено список усіх локалітетів, в яких E. sempervivi був зареєстрований в Україні. Робота ілюстрована мікрофотографіями, отриманими за допомогою сканувального електронного мікроскопа.

Ключові слова: Jovibarba, Sempervivum, іржасті гриби, поширення, морфологія
Тихоненко Ю.Я., Гелюта В.П. Распространение в Украине Endophyllum sempervivi (Pucciniales). Укр. бот. журн., 2017, 74(1): 71-75.

Институт ботаники им. Н.Г. Холодного НАН Украины ул. Терещенковская, 2, Киев 01004, Украина

В мае 2016 г. на кладбище с. Борзова (Волынская обл., Украина) было отмечено эпифитотийное развитие гриба Endophyllum sempervivi на Jovibarba globifera - новом для Украины виде и роде питающих растений. В Северной Европе (Бельгия, Великобритания, Дания, Ирландия, Нидерланды, Норвегия, Швеция), Канаде (Онтарио) и США (северо-восточные штаты) E. sempervivi встречается вне ареала естественного распространения Sempervivum и Jovibarba, но, очевидно, отсутствует в Марокко, Испании южнее Пиренеев, Италии южнее Альп и в западной Азии (Кавказ), несмотря на присутствие там аборигенных видов рода Sempervivum. В статье приведен список всех локалитетов, в которых E. sempervivi был зарегистрирован в Украине. Работа иллюстрирована микрофотографиями, полученными с помощью сканирующего электронного микроскопа.

Ключевые слова: Jovibarba, Sempervivum, ржавчинные грибы, распространение, морфология 